\title{
Micro Houses in Today's Consumer Society
}

\author{
Ildem Aytar Sever ${ }^{1} \quad$ Dogan Zafer Akbulak ${ }^{2}$ \\ Interior Architecture Department, Faculty of Architecture, Mimar Sinan Fine Arts University Istanbul,Turkey
}

\begin{abstract}
Consumption has been a phenomenon since the beginning of human existence. Today, the desire for consuming in the society increases rapidly just like the development of technology. Producers took people out of need and usage focused consuming and turned them into happiness based consumption society. This resulted in them initiating consumption madness and creating an unhappy community that has inaccessible dreams. While all of these were happening metropolises occurred as a result of industrialization, modernization and rapid urbanization. The system determined literally everything; from needs of the people to their communication, from the areas and the style they can live. While doing this, it objectified our houses that are the centers of personal space and furniture in our habitats by rationalizing them. This rationalization turned our habitats into places surrounded by nonfunctional objects. Compared with the past, the consumption madness caused our movement areas to narrow, in contrast to expansion of our habitats. Today, there is a tendency to minimalism to increase quality of life, usage and functionality of our habitats. This tendency's impact also directly affects architecture and interior space design. Consequently, houses becoming widespread day after day, draws attention of users and designers. People tend to increase their quality of lives with less and designers tend to create more functional, more user focused, nondirectly consumption focused and sustainable habitats. These houses are economical in terms of cost and environmentalist in terms of material and size. These houses include furniture that is multifunctional and designed with less is more approach and spacious interiors giving the user an expanse. What is good about micro houses is they are capable of addressing various segments of the society.
\end{abstract}

Keywords: Micro Houses, Minimalist Architecture, Urbanization, Covid-19

DOI: $10.7176 / \mathrm{ADS} / 83-06$

Publication date:July $31^{\text {st }} 2020$

\subsection{Introduction}

Increasingly arousing interest among people, micro houses are buildings which have originated with different approaches of intended use. Micro houses are much more affordable to build and maintain compared to the conventional houses, offering ideal solutions to minimize resource consumption. They have an attitude of minimalism with their structure, assembly and design. They are designed in a minimalist style in terms of both interior architecture and architectural language.

\subsection{Aim and Objectives of the Study}

This study investigates micro houses for their minimalist architectural approach, selection and use of materials for them, the attention paid to details and their environment-friendliness.

\subsection{Definition of Micro House}

Micro houses, which have become extremely popular in recent years, are today popular particularly in the USA and Europe. They are intended to be built using the least amount of materials as possible being as functional and creative as possible.Today, micro houses are built in small spaces sometimes in countryside and sometimes in urban areas.

A micro house must be of a sustainable tiny house design built environment-friendly with the minimum budget possible where inhabitants could meet their own needs and each and every furniture in it must be multifunctional. 'Micro' lexically means extremely small, narrow.

\subsection{Intended Use of Micro House}

The intended use of micro houses is to eliminate the pollution resulting from increasing population, non-functional living spaces and non-environment friendly designs and to find a solution for recent housing shortage from economic point of view. Ultimately, micro houses have quite affordable, environment-friendly and functional designs.

It is also possible for micro houses not only to exist as standalone houses on a land but to be combined to develop mass housing. If a designer produces micro houses from part to whole, they could, in combination, form a postmodern version of today's mass housing

The design style and use of material of the designs are crucial as they are supposed be self-sufficient. The aim is always to build a big life in a small space, maintaining it in the most quality way as possible. 


\subsection{Micro House Designs}

\subsection{Colorado Outward Bound Micro Cabin}

In this research first 'Colorado Outward Bound Micro Cabin', which are micro dormitories designed and developed by University of Colorado Denver, in the United States (Figure 1) was examined.

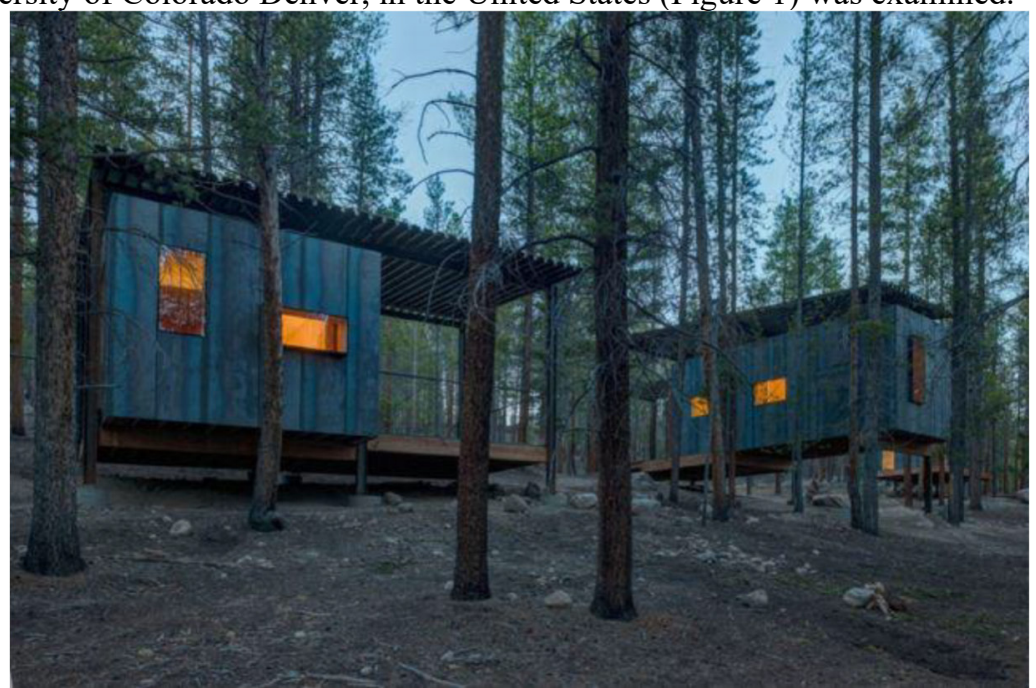

Figure 1: Dormitory, University of Colorado Denver, USA, 2015.

Located within a lodgepole pine forest, the dormitories are built on a steep hillside in the USA. The micro dormitories, the construction of which was completed in 2015, lightly sit on the landscape with a view of mountains through the trees surrounding them.

Designers' team chose to use natural materials in architecture and interior architecture as it is nested within a forest. To blend with the forest, it was formed by combining different types of wood.

The construction of cabins was designed in two separate elements so that they could be completed on site in three weeks. One of these modules is a box and the other a frame. In this design, the box constitutes the living space within the framework while the frame was intended to be used for storage purposes.

This micro house cabins were designed with a porch in front of them, creating negative spaces between them due to layout. The designers team showed a minimalistic approach with both design language and style of building as well as construct.

The designers' team had a lean and clear approach of interior architecture. The construct was designed to perform any function. Besides the naturality of materials, the color and shade of wood were carefully selected with the meticulous details of solutions in material joints. (Figure 2 and 3) The architectural simplicity and minimum use of windows ensured a healthy interior lighting.

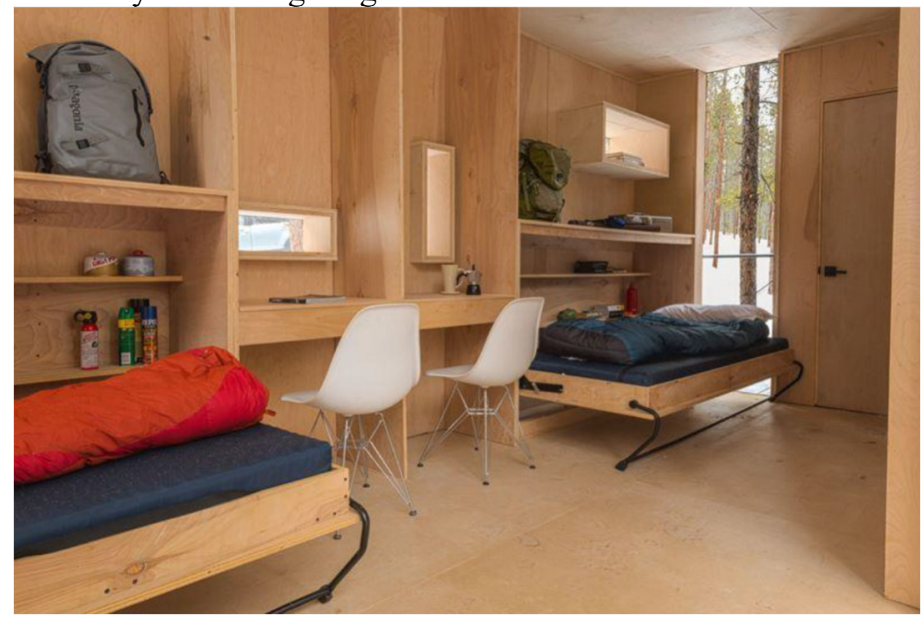

Figure 2 :Dormitory, University of Colorado Denver, USA, 2015. 


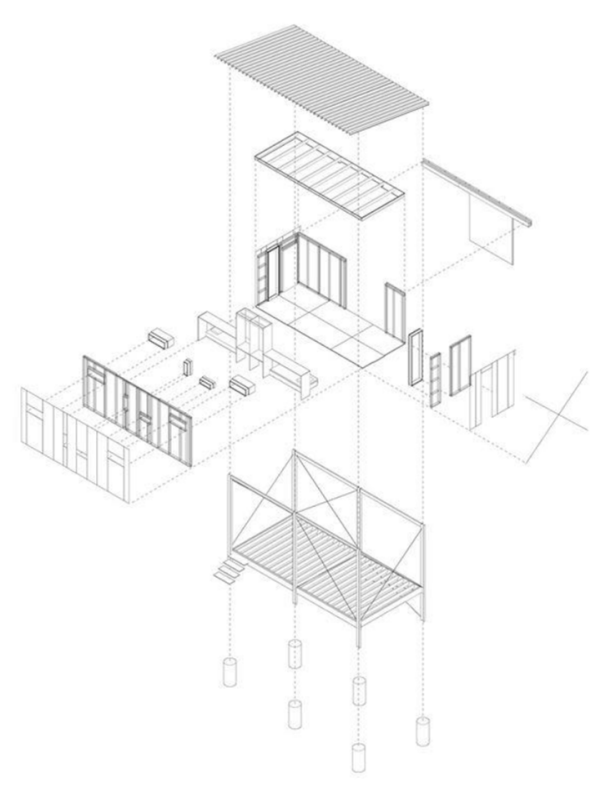

Figure 3 : Dormitory, University of Colorado Denver, USA, 2015.

With their architectural language and interior architectural design as well as all their aspects from their carefully-picked materials and meticulous details, simple and pure look and functional space setup to environmentfriendliness and harmony with their surrounding environment, the dormitories incorporates all characteristics of minimalist approach.

\subsection{MINIMOD}

The micro house 'MINIMOD' designed by MAPA Architects is significant from the point of the models it sets. Built in Brazil in 2013, the building has a floor area of 27 square meters.

MINIMOD, which is an innovative, smart and sustainable design of a micro house is a prefabricated house. Designed with steel frame technology, it features a structure which could be adapted to the needs and requirements of its users. The structure was also designed taking different intended uses into consideration. It could not only be used as a house but also a gathering place for different occasions or even an exhibition space.

MINIMOD was built with a quite low cost thanks to its design and material selection. From this point of view, it is also environment-friendly.

Green vegetation was used on the roof, which makes it gain such a seat within the nature that it is not possible to distinguish it from nature when you look from aerial viewpoint. (Figure 4)

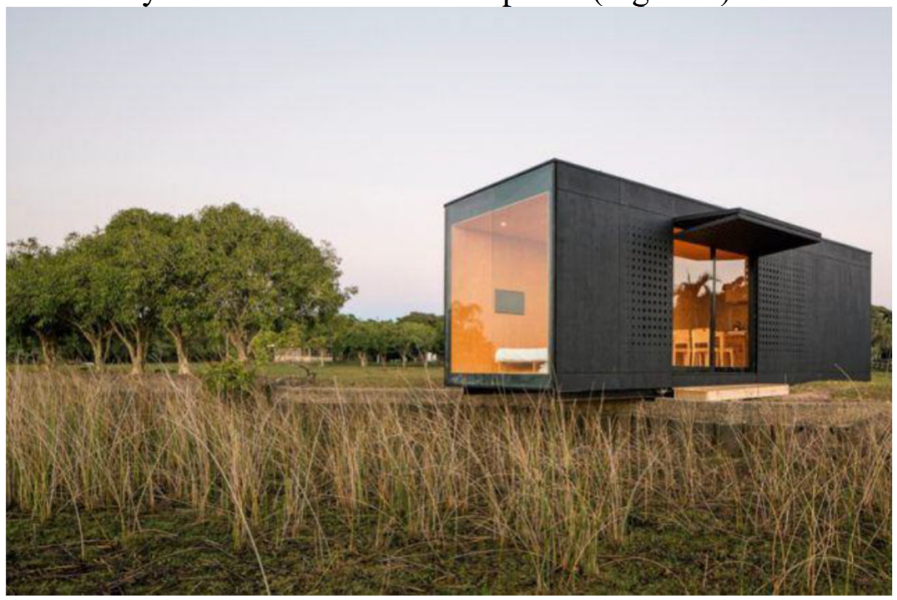

Figure 4 : MINIMOD micro house, MAPA, Brazil, 2013.

The building gives the impression of an empty box due to the openings on façades. Steel frames were used on its exterior façade and structure with a completely wooden interior and in spite of the steely looking geometric structure, the warmness of the natural wooden material used in the interior pleasantly contrast with each other. Thanks to the hinged surfaces on the sides, it forms two small porches. One of them serves as the main entrance of the house. The designers' team created a quite spacious and wide design of plan for this space of 27 square meters in the form of rectangular prism for clients where they could meet all their needs. 
For the interior architecture of the building, there is only one wall which is for partition. The wall also provides passage between spaces on its right and left. The style of building ensures flow from a space to another. (Figure 5)

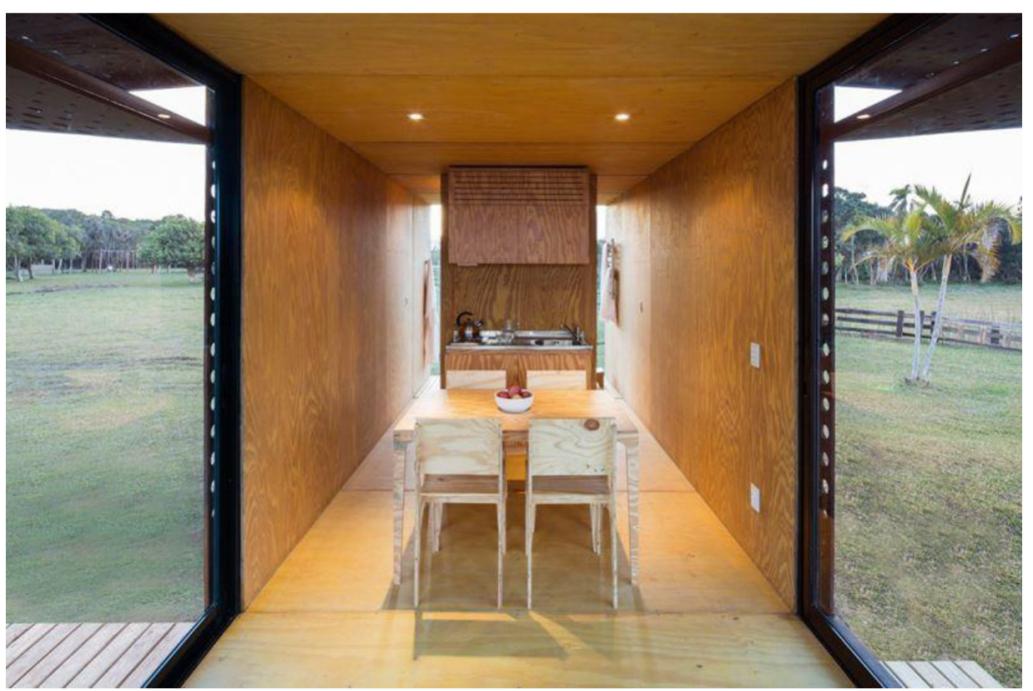

Figure 5 : MINIMOD micro house, MAPA, Brazil, 2013. 73

It can be claimed that MAPA Architects made the most out of little resources with the design, material choice, minimalist and functional approach.

\subsection{APH80}

The micro house APH80 designed by Abaton Arquitectura was built in Spain in 2013. The most significant distinguishing characteristic of it is that it is portable. The client can carry the house to anywhere at any time.

At the design stage, architects defined and built the contours of the building without designing the interior; instead, they adopted a method of design from the inside out (Figure 6).

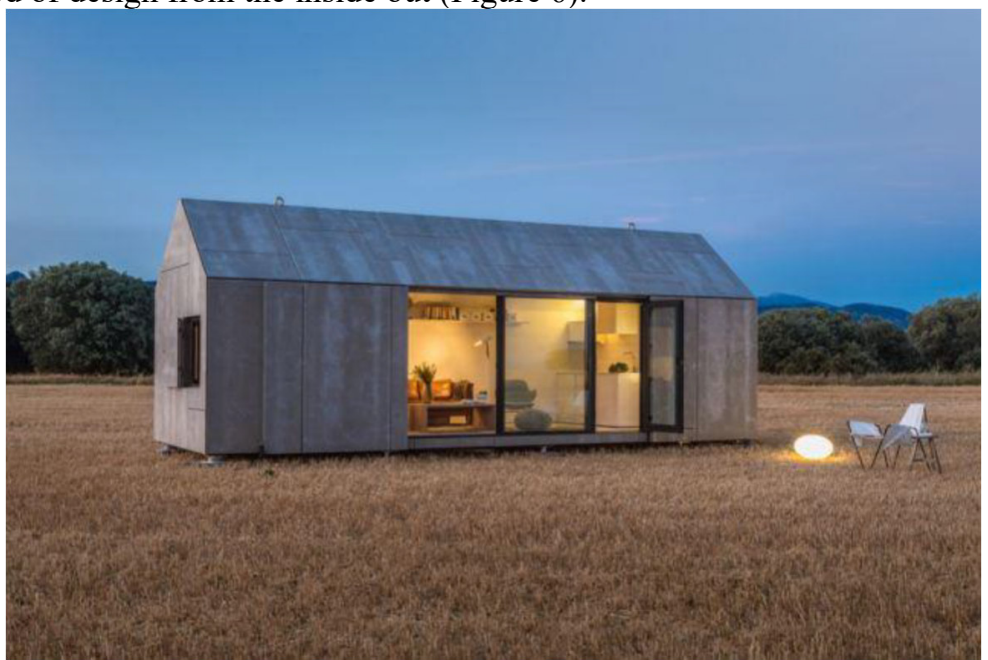

Figure 6 : Portable House APH80, Abaton Arquitectura, Spain, 2013.

For this reason, the area of 27 square meters of the building was resulted from the design. The building was intended for two people to live in and organized accordingly. (Figure 7). On the whole, architects followed a strategy that would give the perception of different interiors and main spaces of living as a single space when looking from outside, and, it can be claimed that as is seen, they managed to do so. When looking from outside, the look of a single mass prevails in the building. 


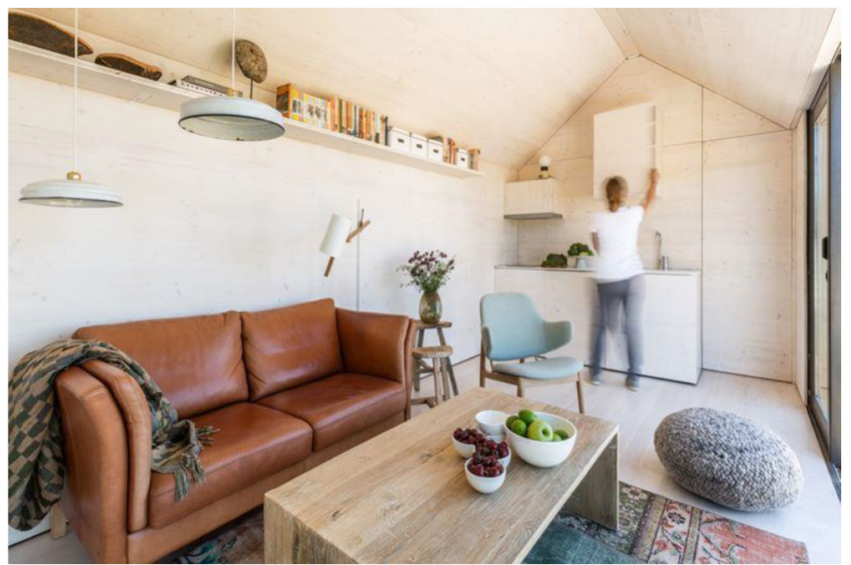

Figure 7 :Portable House APH80, Abaton Arquitectura, Spain, 2013.

Another good characteristic of the building is that most of the materials used are in fact recycled materials. The re-use of the recycled materials when building, and the dimensions of APH80 make us consider it as an environment-friendly house.

The exterior facade of the design, which was constructed with a wooden structure, is grey rendering on wooden panels. Completely disassembling and re-assembling of the cabin take about one day. Thanks to the way it was built and the architecture making it possible for it to be disassembled and assembled, the house could be expanded in the future if and when needed. APH80 is an cost effective design in terms of the material selection and dimensions.

\subsection{Diogene}

The building Diogene is situated within Vitra Campus where the works of famous architects having timeless designs such as Zaha Hadid, Frank Gehry, Nicholas Grimshaw, Tadao Ando and Alvaro Siza are also located. (Figure8)

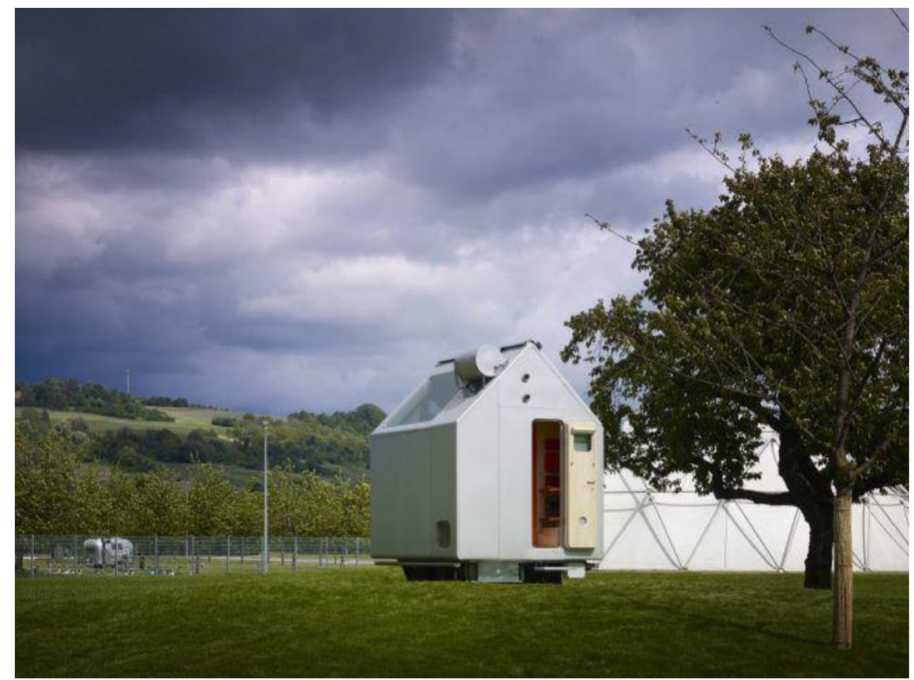

Figure 8 : Diogene, RenzoPiano, Vitra Campus Germany, 2013. 75

It is described as Vitra Campus' 'smallest building but the largest product' in terms of its scale. Diogne is a building placed on an area of just 2.5 x 3.0 meters in Vitra Campus. Designed by the architect RenzoPiano, the building has a floor area of 7.5 square meters and is a self-contained minimal living space.

Diogene, which is among the minimalist architectural buildings, is an important design in terms of setting up a living within a small space.

The design story of Diogene originates from Piano's fascination of what the smallest area where one could live could be, from his student days. The architect who, over time, had sought an answer for this question, which had puzzled his brain when he was a student, put this idea into practice and designed this micro house.

The architect expresses that he designed it not for a specific client but as a doctrine of his own journey of architectural discovery.

The name of the building originates from the ancient Greek mythology. The story is that the god, which is known as the Diogenes, the Sinopean, in Turkey was said to live in a barrel. In fact, a truly extraordinary design emerged within the framework of its story and ordinary approach. 
The building which is so small that you can carry with a lorry has all systems one might need to live in it.

The building was designed with a sustainable technique, as well. The Diogene has a water collection system and the technology necessary for power generation within its current dimensions.

Diogene, which has an aluminum coating on the exterior façade, was built with wooden building elements.

The interior of Diogene consists of a space divided into two by a wall. One of the spaces created by the wall is the part where a foldable table and seat are placed and the other is where a small kitchen and bathroom spaces are situated.

The architect used a simple language in interiors. The floors are coated with wooden floorings. He made interiors look spacious with the shade of the wood he selected. (Figure 9)

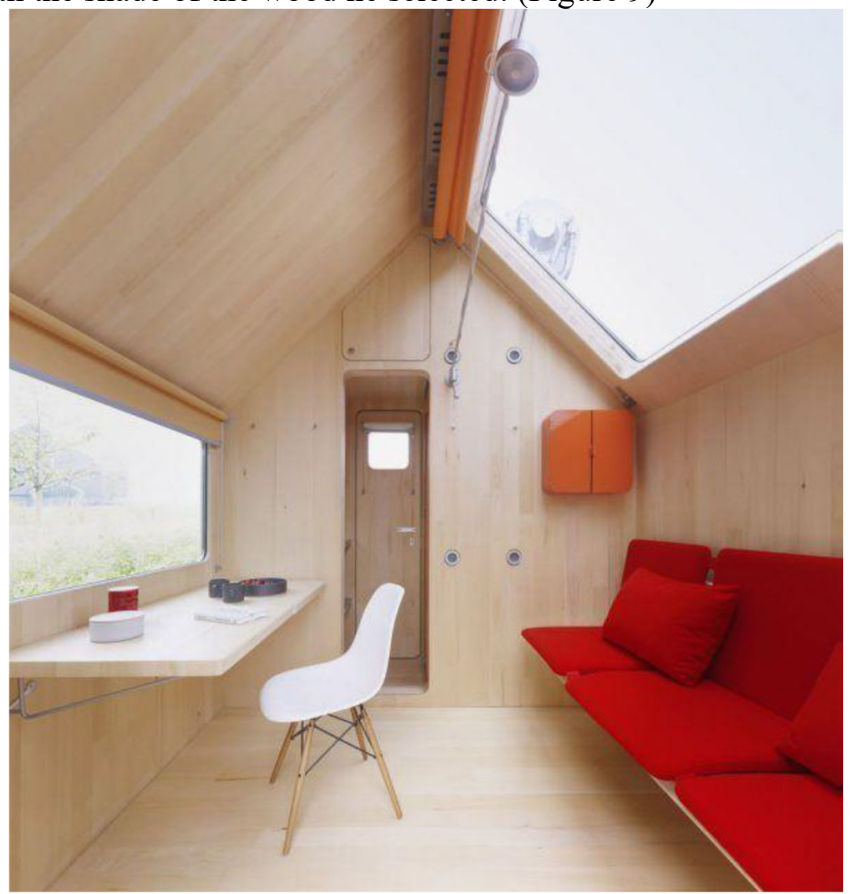

Figure 9 :Diogene, Renzo Piano, Vitra Campus Germany, 2013.

Diogene is a model which we could describe as the most minimalist design of the world given its architecture, interior design and scale.

\subsection{Micro house by Studio Lui Lubin}

The micro house by Studio Lui Lubin team was designed considering the minimum area needed by people to sit, stand and lie in the interiors. (Figure 10).

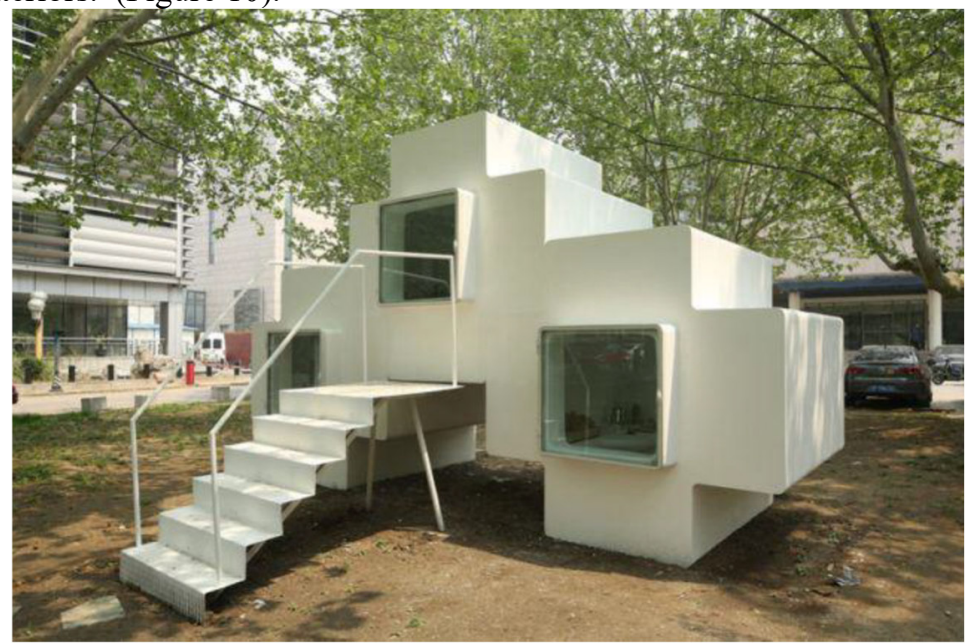

Figure 10 :Micro House, Studio Lui Lubin, China, 2013.

The geometrical form of it is in the form of a combination of the furniture elements in the interiors. Its architecture allows for larger buildings by combining more of it. In fact, it is a single standalone unit but combining more of these units could form a micro version of mass dwelling. (Figure 11 and 12). 

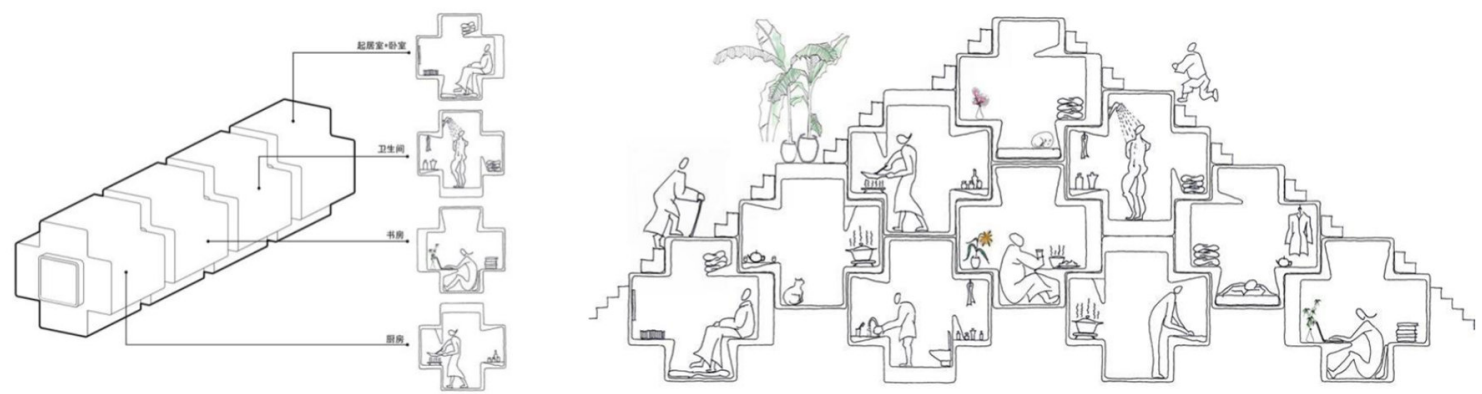

Figure 11-12 : Micro House, Studio Liu Lubin, China, 2013.

The building is mainly built with fiber-reinforced foam composite. This material renders it very lightweight. The dimensions of the building allow it to be fit in a container for transportability.

It was designed with a minimal approach with the use of white in the exterior and interior and solid geometrical form.

The minimalist influence on the architecture of the building and the designers' team's approach to materials can also be seen in the interior. The user can easily meet their needs in the living space. White color and yellow light was preferred in the interior. The modular and multifunctional furniture were designed uniquely for this micro house. (Figure 13)

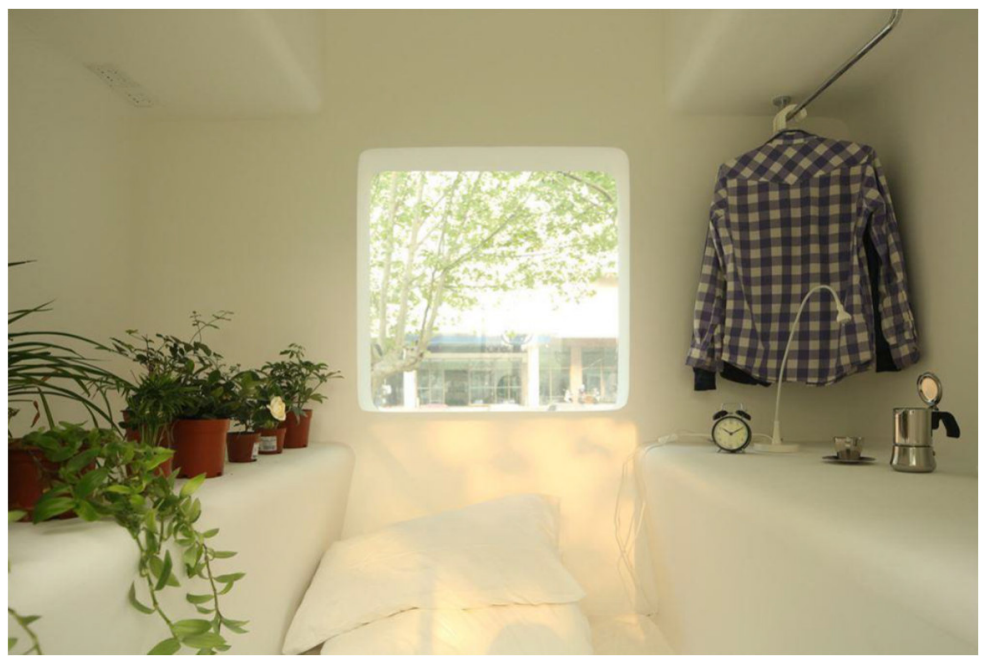

Figure 13 : Micro House, StudioLiuLubin, China, 2013.

This project implemented by Studio Liu Lubin team could be combined unit by unit to create many design variations of different architectures. From this point of view, its design could be considered quite resilient.

Given the way in which it was built and its functions, it has a minimalist design. Being cost-effective and environment-friendly thanks to the materials used and the dimensions, the design has also a minimalist attitude in terms of the selection and utilization of materials.

\subsection{KODA House}

Micro house "KODA House", which took a place for itself in the Small Project Prize list of World Architecture Festival 2016, was exhibited in 2015 Talinn Architecture Biennale. The building designed by Kodasema Architecture team was built in Estonia in 2016 (Figure 14). 


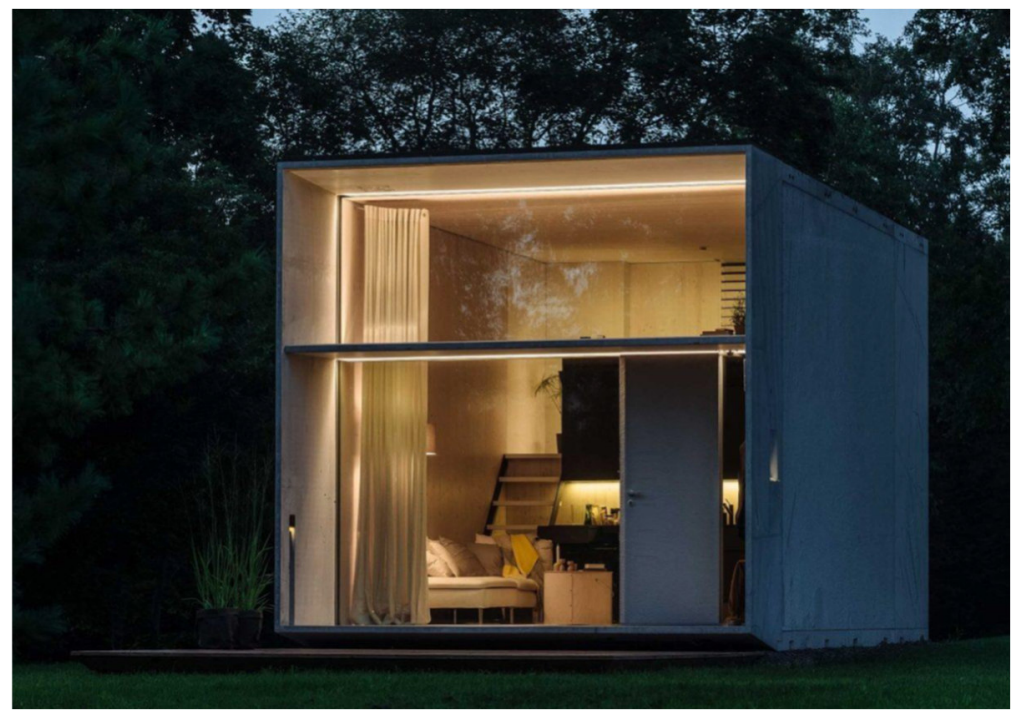

Figure 14 : KODA, Kodasema Architecture, Estonia, 2016.

What makes KODA special is that it has smart house technology. This way, as a house finding out about and adapting to its surrounding environment, it is a quite sustainable and environment-friendly design. Fronts are made of light concrete blocks specially designed for KODA. The living space front is all along glass. This opening helps it tone down the coldness of grey concrete of exterior with the colors and lighting of the interiors.

A remarkable open plan with a mezzanine is used in the interior of the building. Besides, it can be seen that the materials used were carefully selected. No crowd of materials was created. The house was designed as a building which has minimum floor space enabling two people to live in.

Being multifunctional, all the furniture was made specially keeping the client's needs in mind. Interior walls are covered with wooden panels while a spacious environment was created with the shades and type of wood of the panels used on the walls and floorings. In contrast, dark color wood and fabrics of various textures were chosen for furniture. Black color materials were used in wet areas and are distinguished from the living space with the approach of dark in light. The light-dark relationship adds a different mood to design in terms of color and spatial approach. (Figure 16).

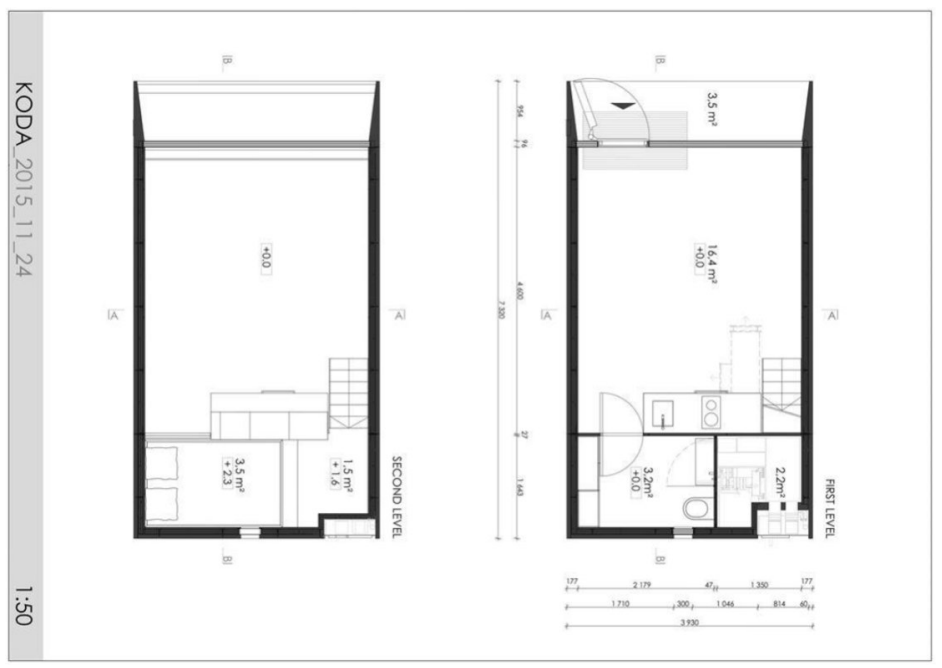

Figure 15: KODA, Kodasema Architecture, Estonia, 2016. 80 


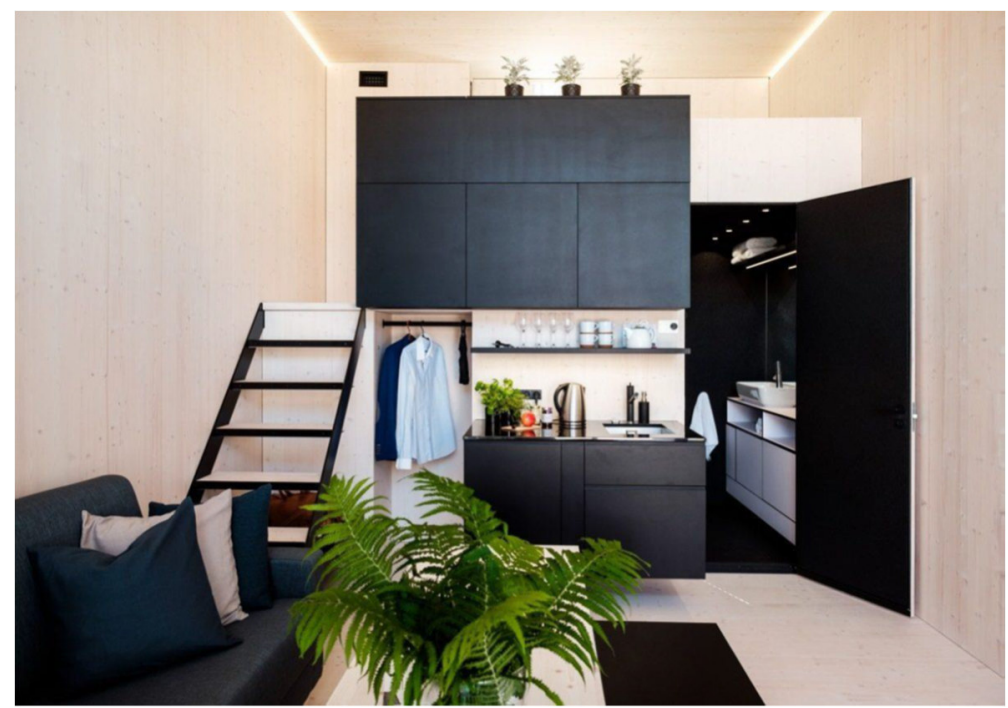

Figure 16 : KODA, Kodasema Architecture, Estonia, 2016.

The designer company adopts a reductive attitude considering the scale of the project and their approach to design. Furthermore, it is a good micro house in that it is sustainable and has smart house systems. No matter how small-scale the project is, it is perceived as spacious by user thanks to its height. The rigid geometrical form of the grey exterior is softened up by the opening and a different architectural effect was created, which is day and night.

All things considered, KODA House is a micro house design which falls into the minimalist movement and it is the most environment-friendly one among the minimalist buildings built by today's technology.

\subsection{Covid 19 Panndemic and Homelessnes \\ 3.1 Covid 19 Panndemic}

The COVID-19 pandemic, also known as the coronavirus pandemic, is an ongoing global pandemic of coronavirus disease 2019 (COVID-19), caused by severe acute respiratory syndrome coronavirus 2 (SARS-CoV-2).The outbreak was first identified in Wuhan, China, in December 2019. The World Health Organization declared the outbreak a Public Health Emergency of International Concern on 30 January 2020 and a pandemic on 11 March. As of 13 July 2020, more than 12.9 million cases of COVID-19 have been reported in more than 188 countries and territories, resulting in more than 571,000 deaths; more than 7 million people have recovered. There is no known vaccine or specific antiviral treatment.Primary treatment is symptomatic and supportive therapy.

Recommended preventive measures include hand washing, covering one's mouth when coughing, maintaining distance from other people, wearing a face mask in public settings, disinfecting surfaces, increasing ventilation and air filtration indoors, and monitoring and self-isolation for people who suspect they are infected.

COVID-19 spreads primarily when people are in close contact and one person inhales small droplets produced by an infected person (symptomatic or not) coughing, sneezing, talking, or singing. The WHO recommends 1 meter (3 ft) of social distance; the US Centers for Disease Control and Prevention (CDC) recommends 2 meters $(6 \mathrm{ft})$.

Strategies for preventing transmission of the disease include maintaining overall good personal hygiene, washing hands, and physical distancing measures. Individuals may apply social distancing methods by staying at home, limiting travel, avoiding crowded areas, using no-contact greetings, and physically distancing themselves from others.Many governments are now mandating or recommending social distancing in regions affected by the outbreak. Non-cooperation with distancing measures in some areas has contributed to the further spread of the pandemic.

The maximum gathering size recommended by U.S. government bodies and health organisations was swiftly reduced from 250 people (if there were no known COVID-19 spread in a region) to 50 people, and later to 10.0 . 22 March 2020, Germany banned public gatherings of more than two people. A Cochrane review found that early quarantine with other public health measures are effective in limiting the pandemic, but the best manner of adopting and relaxing policies are uncertain, as local conditions vary.

\subsection{Homelessnes}

Homelessness is defined as living in housing that is below the minimum standard or lacks secure tenure. People can be categorized as homeless if they are: living on the streets (primary homelessness); moving between temporary shelters, including houses of friends, family and emergency accommodation (secondary homelessness); living in private boarding houses without a private bathroom or security of tenure (tertiary homelessness). 
Homelessness satisfies the first rung in Maslow's Hierarchy of Needs, primarily due to their lack of adequate fundamental resources, including food, shelter, and water.

It is estimated that 150 million people are homeless worldwide.Habitat for Humanity estimated in 2015 that 1.6 billion people around the world live in inadequate shelter.

Indeed, homeless people often present multiple chronic conditions; have difficulty access in health services; live together in shared, overcrowded and cramped accommodation, or on the streets; might not have regular access to basic hygiene supplies or showering facilities. They are, therefore, vulnerable to high rates of infection and mortality without appropriate intervention.

\subsection{Conclusion}

The negative psychological, economic and ecological effects of the consumer society in which we currently live and the phenomenon of consumption that constitutes the building block of this society can be seen on our living spaces and environment.

The necessity of more efficient use of the gradually decreasing world resources reflects to the architecture and thus to interior design. The significant elements of these reflections include the relationship and harmony of architectural style with ecology, the effects on the architecture and thus to interior design thanks to a reductive approach towards the decreasing resources, and lastly, the improvement of life quality by offering enough, but not more than needed, living space to users.

Apart from these topics, one of the biggest and even global social problems is recently the Covid-19 pandemic, which has rapidly spread all around the world due to globalization. The pandemic showed us how great importance sanitation and hygiene have in our living spaces as well as public spaces. Micro houses might be the best solution for homeless people during pandemics and for social isolation in future. Mini house villages can make a significant positive contribution to flattening the curve of disease transmission and they will cost far less than extended hotel stays and can remain in place for years.

The measures that we try to take against Covid-19 virus are the proofs of that being a design element which is impossible to be ignored by designers no matter what the function in the fields of architecture and interior design.

The fact that micro houses could be designed without exploiting world resources, in harmony with nature, environment friendly and functionally and the effort to create great and quality living spaces in small areas distinguish them from other buildings in terms of sanitation and hygiene.

That it is quicker and easier to ensure hygiene in the spaces created with minimalist approach and that they give priority to usage instead of consumption carried micro houses and micro living spaces to an important point against possible threats of pandemic of Covid-19 etc. Their smaller size and a more explicit design of personal private spaces mean that it is easier to clean and ensure hygiene.

How micro houses discussed in this article would make our living spaces more efficient and livable within the context given above are exemplified. However, micro houses show their importance for today's society with the simple and hygienic structure as well as the environmental-friendly and healthy environment offered by them.

\section{References}

Akbulak, D. Z. (2019). Günümüz Tüketim Toplumunda Minimalizm ve Mikro Evler. Mimar Sinan Güzel Sanatlar Üniversitesi Fen Bilimleri Enstitüsü İç Mimarlık Ana Bilim Dalı Yüksek Lisans Tezi.

Akbulut, M., \& Yüksel, U. (2009). Tüketim Odaklı Mimarlığın Son Yıllardaki Yeni Ürünleri: Rezidanslar MEGARON. 110-117.

Akyildiz, A. (2006). Hacettepe Universitesi Guzel Sanatlar Fakultesi Hacettepe Universitesi Guzel Sanatlar Fakultesi 8. Ulusal Sanat Sempozyumu. Sanat ve Popüler Kültür. içinde Ankara: Kariyer Matbaacilık.

Alberto B. CoViD-19 in Italy: homeless population needs protection, Recenti Prog Med 2020; 111: 295-296

Altinyildiz Artun, N., \& Ojalvo, R. (2012). Arzu Mimarlı̆̆ı. 14-302.

Artun, A., \& Aliçavuşoğlu, E. (2009). Bauhaus Modernleşmenin Tasarımı. 13-565.

Aslaner Geceoğlu, F., \& Aydinli, S. (2014). Mimarlık Üretimi Üzerine Bir İç Hesaplaşma: Tüketim Dinamiklerinin Uzantısında Mimari Bir Duruş - Tasarım + Kuram. 54-73.

Ataseven, O. (2012). Dan Flavin'in Mekanı Dönüştüren Işığı ve Minimalizm - ART-E. 85-94.

Aureli, P. (2015). Az Yeterlidir Mimarlık ve Asketizm Üzerine. 5-63.

Aydoğan, F. (2009). Tüketim Kültürünn Gölgesinde Kentler - İ.İ.B.F. Dergisi. 203-213.

Baudrillard, J. (1997). Tüketim Toplumu. 15-236.

Bocock, R. (1999). Tüketim. 22-127.

Dal, N. E. (2019). Tüketim Toplujmu ve Tüketim Toplumuna Yöneltilen Eleştiriler Üzerine Bir Tartışma Mehmet Akif Ersoy Üniversitesi Sosyal Bilimler Enstitüsü Dergisi. 2-16.

Dol, A., \& Avşar, P. (2001). Minimalizm Akımı Kapsamında Nesne Anlayışının Yeniden Değerlendirilmesi - İdil Dergisi. 2-10.

Ertürk, M. (2011). Minimalizm'in Doğuşu Ve Mimaride Biçim Açısından Minimalizm Değerlendirmesi - İstanbul 
Teknik Üniversitesi, Sosyal Bilimler Enstitüsü, İç Mimari Tsarım Anabilim Dalı, Yüksek Linsans Tezi. 5159.

Foster, H. (2002). Tasarım Ve Suç. 9-188.

Gay, P. (2017). Modernizm Sapkınlığın Cazibesi. 15-594.

Huang C, Wang Y, Li X, Ren L, Zhao J, Hu Y, et al. (February 2020). "Clinical features of patients infected with 2019 novel coronavirus in Wuhan, China". Lancet. 395 (10223): 497-506. doi:10.1016/s01406736(20)30183-5. PMC 7159299. PMID 31986264.

İnam Karahan, Ç. (2015). Sanatta Çağdaş Bir Dönüm Noktası Minimal Sanat - Sobiad. 19-26.

Irmak, C. H. (Ocak 2002). Mimarlıkta Yalınlık Ve Minimalist Tavır - İstanbul Teknik Üniversitesi, Fen Bilimleri Enstitüsü, Mimarlık Anabilim Dalı, Bina Bilgisi Programı Yüksek Lisans Tezi. 5-80.

Islakoğlu, P. M. (2005). Mimarlıkta Minimalizm - Ege Mimarlik. 14-19.

Millburn, J. F., \& Nicodemus, R. (2018). Minimalizm Anlamlı Bir Yaşam. 12-131.

Millburn, J. F., \& Nicodemus, R. (2018). Minimalizm Geriye Kalan Her Şey. 15-242.

Miller, G. (2012). Tüketimin Evrimi. 7-376.

Nussbaumer-Streit B, Mayr V, Dobrescu AI, Chapman A, Persad E, Klerings I, et al. (April 2020). "Quarantine alone or in combination with other public health measures to control COVID-19: a rapid review". The Cochrane Database of Systematic Reviews. 4: CD013574. doi:10.1002/14651858.CD013574. PMC 7141753. PMID 32267544.

O'doherty, B. (2010). Beyaz Küpün İçinde. 9-130.

Özcan, O. (2018). Minimalizm Ve 'Sil Gözyaşlarını Artık Hiçbir Şey Eskisi Gibi Olmayacak' Adlı Oyunda Minimalizmin İzdüşümleri. Görünüm, 29-33.

Özgüt, Ö. (2002). Mimarlık Ve Tüketim. 10-63.

Roth, L. (2002). Mimarlığın Öyküsü. 29-674.

Schleifer, S. (2016). Mini Homes - Loft Publication. 14-503.

Senemoğlu, O. (2017). Tüketim, Tüketim Toplumu Ve Tüketim Kültürü: Karş1laştırmalı Bir Analiz. İnsan\&İnsan, 67-84.

Şengül, H. (2002). Tüketim Toplumu, Tüketim Kültürü ve Tüketim Merkezleri - Ege Mimarlik. 40-41.

URL-1. (2018, Kasım 27). İhtiyacımız Olmayan Ürünleri Satın Almamızın Sebebi: Diderot Etkisi. CEOtudent: https://ceotudent.com/diderot-etkisi-nedir

URL-2. (2016, Temmuz 18). Minimalist bir ev: Az aslında çoktur. Homify: https://www.homify.com.tr/yeni_fikirler/1030715/minimalist-bir-ev-az-aslinda-coktur

URL-3. (2019, Şubat 26). Minimalist Prefabrik Ev. Yeşil Odak: https://www.yesilodak.com/minimalist-prefabrikev

URL-4. (2017, Haziran 16). Minimalizm : Less is More. CEOtudent: https://ceotudent.com/minimalizm-less-ismore

URL-5. (tarih yok). The Minimalists. https://www.theminimalists.com/

URL-6. (2014, Eylül 2). What would our hımes look like if designed around how we use them? Treehugger: https://www.treehugger.com/green-architecture/what-would-our-homes-look-if-designed-around-how-weuse-them.html

URL-7. (2015, Ocak 13). Kavrakoğlu. Çağdaş Sanata Varış 114/Minimalizm 1: https://kavrakoglu.com/cagdassanata-varis-114-minimalizm-1/

URL-8. (2017, Haziran 11). KODA: The Solar Powered Micro-Home. iReviews: https://www.ireviews.com/news/2017/07/11/kodasema-koda-micro-home

URL-9. (2016, Mart 7). ARKITERA. Yeni Proje Dostası: Mikro Mekanlar Burcu BİLGİÇ: http://www.arkitera.com/haber/26541/yeni-proje-dosyasi--mikro-mekanlar

URL-10. World Health Organization (WHO). "Naming the coronavirus disease (COVID-19) and the virus that causes it".

URL-11. World Health Organization (WHO) "Novel Coronavirus-China".

URL-12. World Health Organization (WHO) "WHO Director-General's opening remarks at the media briefing on COVID-19-11 March 2020"

URL-13. World Health Organization (WHO) "Q\&A on coronaviruses (COVID-19)" 17 April 2020.

URL-14.Johns Hopkins University. COVID-19 Dashboard by the Center for Systems Science and Engineering (CSSE) at Johns Hopkins University (JHU)"

URL-15.U.S. Centers for Disease Control and Prevention (CDC) "How COVID-19 Spreads". 2 April 2020.

URL-16.CDC.org. Centers for Disease Control. CDC staff (27 May 2020). "COVID-19 Employer Information for Office Buildings. Develop hazard controls using the hierarchy of controls to reduce transmission among workers. Include a combination of controls noted below".

URL-17.Government of the United Kingdom. "Coronavirus (COVID-19): What is social distancing?-Public health matters" 